Article History:

Submitted:

16 December 2021

Reviewed:

17 December 2021

Edited:

21 December 2021

Article Accepted:

27 January 2022

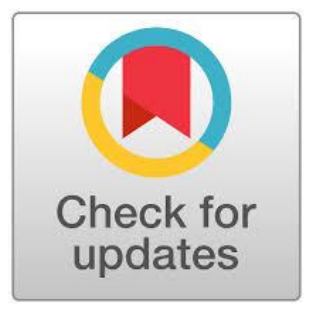

\section{Exploring Online Learning Tools Used by EFL Teachers during the COVID-19 Pandemic}

\author{
Mariska Intan Sari ${ }^{*}$ ), Aura Amalia Putri \\ Universitas Muhammadiyah Yogyakarta, Indonesia \\ ${ }^{*}$ Corresponding author email: mariska.intan@umy.ac.id
}

DOI: https://doi.org/10.18196/ftl.v7i1.13407

Abstract

COVID-19 pandemic has affected many sectors of human life, including the educational sector. This situation has forced the government to impose the School-from-Home policy for all levels of education in Indonesia since March 2020. Teachers need to be aware of this change and adapt to the situation in this situation. Media use in learning matters since the learning process is switched to online learning. Thus, this paper aims to explore the online learning tools utilized by EFL teachers and EFL teachers' consideration in choosing online learning tools during the COVID-19 pandemic. This research employed a qualitative approach by conducting in-depth interviews with five EFL teachers from five different state senior high schools in Yogyakarta Special Region, Indonesia, who have taught English for at least two years and have used online learning tools during the COVID- 19 pandemic. This research found six types of online learning tools used by the EFL teachers: learning management systems, assessment tools, chat and messages, video learning and sharing platform, content maker, and video conferencing tools. Moreover, concerning the teachers' considerations in utilizing these online learning tools, they explained that they should be easy to use, accessible, cost-effective, attractive, and lightweight. Other teachers could also use these considerations to choose the online learning tools utilized in their teaching and learning processes.

Keywords: EFL teachers; online learning tools; EFL teachers' consideration 


\section{Introduction}

\section{Background of the Research}

In the Industrial Revolution 4.0 era, online learning is not new. It grows fast, which can be seen from the rapidly growing online learning platforms such as EdX, Udemy, and Coursera, offering free access to some online courses. Also, some schools, universities, and other educational institutions worldwide have applied blended learning, a combination of offline and online meetings for the teaching and learning process. However, not all schools, universities, and other educational institutions have applied online learning, be it fully online learning or blended or hybrid learning, before the COVID-19 pandemic, especially in Indonesia.

Then, the COVID-19 pandemic hit the world, including Indonesia, and urged the Indonesian government to impose some policies to avoid spreading the virus. This virus has affected many sectors of public life, including the educational sector. According to UNESCO (2020), due to the COVID-19 pandemic, most governments temporarily closed the educational sector to minimize the spread of the COVID-19 virus. Both students and teachers are affected in teaching and learning processes in that the teaching and learning process must be switched from offline mode to online mode. The Indonesian government issued a Study from Home policies for all education levels in the middle of March 2020 to support the government's social distancing policies (Ministry of Education and Culture, 2020).

Thus, all the teaching and learning processes have been conducted online afterward. This condition causes teachers to have to adapt to this new online environment. Online learning can be done with the help of technology. One form of technology used is online learning tools such as learning management systems, social networking tools, and web 2.0 tools. Gunawan et al. (2019) stated that online learning tools like Learning Management Systems (LMS) could help maximize online learning because they can provide convenience for students. Moreover, the EFL teachers must also be aware that they must adjust their teaching methods and technique for online teaching. Also, they need to be aware if they need to utilize online learning platforms in teaching and learning processes.

However, in implementing online learning, some problems are faced by EFL teachers in a state senior high school in Yogyakarta. Based on an informal interview with one of the EFL teachers at a state senior high school in Yogyakarta, the EFL teachers reported the problem they 
faced during the COVID-19 pandemic. Especially at the pandemic's beginning, the teaching and learning process did not run effectively because both the teachers and the students had not yet been familiar with online learning tools. Thus, the EFL teachers must struggle to find the best online learning tools which can suit both the teachers' and students' needs. Now that the online teaching and learning mode has been conducted for about a year, the researchers are interested in conducting a study entitled Exploring the Online Learning Tools used by EFL Teachers during the COVID-19 pandemic. This research aims to explore the online learning tools used by the EFL teachers during the teaching and learning process in the COVID-19 pandemic and the considerations these EFL teachers have in choosing these online learning tools.

The past studies on the English learning tools and teaching during the COVID19 pandemic have been plenteous. The study from Gunawan et al. (2020) entitled Variations of Models and Learning Platforms for Prospective Teachers during the COVID-19 Pandemic Period was conducted to find online learning tools used in online learning and how the teachers use those online tools in learning. In addition, Hamat and Embi (2010) showed that the constructivism theory could also be used in designing online learning. The role of constructivism theory here is to guide communication and collaboration tools. Thus, this research focuses more to EFL teachers' online tools and their considerations in choosing online learning tools during pandemic. Additionally, the researcher chooses EFL school teachers because the researcher believes that students' characteristics at school and university are different. Therefore, the approach and the treatment during online learning using online learning tools might also be different. Donche and Petegem (2010) explained that the students in high school are unlike students at the university level; therefore, the learning strategies will also be different.

Furthermore, secondary school students do not need sophisticated learning strategies like those higher education students. Therefore, this research aims at scrutinizing the online learning tools used by the EFL teachers at the secondary level. The research questions are formulated as follows:

1. What are the EFL teachers' online learning tools?

2. What are the EFL teachers' considerations in choosing online learning tools? 


\section{Literature Review}

\section{Online Learning Tools}

Due to the COVID-19 pandemic, all schools have switched to online learning. Online learning is defined as learning that can implement synchronous and asynchronous using various tools such as smartphones and laptops with internet access (Dhawan, 2020). Afterward, teachers can use online learning tools that suit their individual needs in implementing online learning during the pandemic. Eady and Lockyer (2013) stated that tools are the sources to support the teaching and learning process. According to Eady and Lockyer (2013), some examples of tools are communication tools such as word-processing, presentation and publishing software, webpage authoring tools, email, and online discussion forum. Also, there are collaborative learning tools such as wikis, blogs, and classroom webpages. Then to support students in writing skills, they can use a spelling checker and enhance their vocabulary by using Thesaurus. The tools that the EFL teachers use help the students in learning by giving the students chance to create, manipulate, and exchange information with others through computer devices or another computer network.

Additionally, the tools help the students learn and can ease the teacher in online learning. According to Reimers et al. (2020), a tool is defined as an instrument to assist teachers in managing their teaching and learning. For instance, communication tools, learning management systems, or other tools that teachers, parents, or students can create or access educational content. Therefore, by seeing the explanation above, online learning tools can be concluded as a tool that can help the teachers in online learning by using different devices (e.g., laptop and smartphone) with internet access. The purpose is to help students make and utilize their learning and share information.

There are many types of online learning tools. Atmojo and Nugroho (2020) have categorized them into eight categories. There are learning management systems, chat and messages, video learning and sharing, video conferencing tools, assessment tools, content maker tools, online learning providers. Learning management system tools can be used in the teaching and learning process during the COVID-19 pandemic, namely, Moodle, Google Classroom, and Google Meet. Then, chat, and messaging tools are used during this pandemic, such as Line, 
WhatsApp, and Telegram. Not only that, for assessment tools, there are platforms that can be used, namely Google Forms and Quizlet. Moreover, video and sharing tools, like YouTube, can be used in the teaching and learning process. Hence, there are many ways to conduct online learning tools during the COVID-19 pandemic.

\section{EFL Teachers' Consideration}

In choosing the online learning tools, the EFL teachers consider several things to choose suitable online learning tools in the teaching and learning process. Gunawan et al. (2020) stated that lecturers' most widely used online platforms are WhatsApp because lecturers and students have this application on their smartphones. Besides, many students claimed that they like using WhatsApp because WhatsApp can be used everywhere and anytime. Gunawan et al. (2020) had a similar result with a study from Atmojo and Nugroho (2020). EFL teachers stated that they used Google Classroom because of its practicality and it did not spend much internet quota to get a stable internet connection. These studies concluded that the teachers or lecturers chose online learning tools because of their accessibility.

The next one is the online learning tools easy to use. The study from Gunawan et al. (2020), another online learning tool, was chosen by lecturers because of its easiness. The lecturers stated that using Google Classroom or LMS makes it easier for them to manage the class, to create creative and innovative learning. Ventayen et al. (2018) stated that Google Classroom is highly recommended because it was easy to operate this tool. This tool has exclusive features that fulfill lecturers' and students' needs. This explanation shows that if the lecturers or the teachers consider the easiness of choosing online learning tools.

Then, online learning tools that the teacher uses should not be expensive for the students. The online learning tool should not consume much data for the students. The tool should consume fewer data. Atmojo and Nugroho (2020) found that EFL teachers chose Google Classroom as one of the tools in online learning because this tool does not spend much internet data to get a stable connection.

Lastly, the online learning tools should be interesting. The online learning tool should be interesting for the students, meaning that the online learning should cover all aspects, 
including audio, video, or animation. According to Almurashi (2016), students enjoy watching YouTube because it covers audio and video. Therefore, students feel happy and enjoy during the session.

\section{Previous Studies}

This part of the research includes reviewing related studies to the research topic. The first related previous study is from Gunawan et al. (2020) with Variations of Models and Learning Platforms for Prospective Teachers during the COVID-19 Pandemic Period. This research used a descriptive qualitative design. It was conducted at LPTK Mataram and involved participants who were 212 lecturers. The method used to survey and focus group discussion (FGD). The survey was conducted to obtain information on the implementation of online learning.

Meanwhile, the focus group discussion (FGD) is to seek other information from the lecturer. The study describes the variation of models and platforms used in online learning for prospective teachers during the social distancing period. The study showed that the lectures used online learning tools such as WhatsApp, Email, and LMS (Learning Management System) and challenges in online meetings.

The second study discusses constructivism in the Design of Online Learning Tools from Hamat and Embi (2010). The methodology of this research used a qualitative approach by analyzing selected documents (journal articles), and the researchers analyzed constructivism mentioned in online learning. Then, this study aims to serve a concept of the principle of constructivism to online learning. Next, this research's findings showed that constructivism is mainly used for online learning tools and the activities related to communication and collaboration. The result reported that the constructivism theory was used to design online learning. Here, constructivism guided online communication, collaboration, and personal construction of knowledge and constructivism. 


\section{Method}

This research applied a qualitative research approach and descriptive qualitative design. According to Lambert and Lambert (2012), a qualitative descriptive research design is acceptable among other qualitative designs (e.g., phenomenological, grounded theory, and ethnography). The qualitative descriptive design is also functional when the researchers want to know events, who, what was involved, and where the event took place. In addition, according to Merriam (1998), the findings of qualitative descriptive design can provide more description from individual experience. Therefore, this research design is suitable to answer the research question.

The participants of this research were five EFL teachers from five different state senior high schools in Yogyakarta. These participants were selected based on the criteria that the researchers have set. The fundamental reasons for selecting the participants were that all participants used online learning tools during the COVID-19 pandemic, and EFL teachers have taught English for at least two years. The researchers used pseudonyms to refer to the participants to protect their identity. They are Belle, Aurora, Elsa, Cinderella, and Aladdin. Belle has taught English for sixteen years, Elsa for nine years, Aurora for six years, Cinderella for nine years, and they all have used online learning during the COVID-19 pandemic. Finally, Aladdin has taught English for twelve years. He is also the head of the English society at school. He also used online learning tools since the pandemic hit Indonesia. Therefore, since the participants have taught English for more than two years and actively used online learning tools during the COVID-19 pandemic, the researchers believed that all participants could answer the interview questions in detail and elaboratively.

Then, the researchers used a semi-structured interview as the type of interview. A semistructured interview involves a set of open-ended questions that can acquire in-depth information and allow a spontaneous response from the participants (Ryan et al., 2009). In conducting the interview, the researchers used Bahasa Indonesia since Bahasa Indonesia is the mother tongue of both participants and interviewees. Hence, using Bahasa Indonesia can avoid misunderstandings between them. Also, the interviewees can better express themselves using their mother tongue so that researchers can obtain rich data from them. The interview sessions lasted around 40-50 minutes for each participant. The interview was recorded using a recorder 
in the interviewers' mobile phones to ensure no data loss from the interview sessions. In this research, the researchers also did note-taking to write essential points to help the researchers create follow-up questions for the participants to enrich the data.

In maintaining the credibility of the research, the researchers did member checking to ensure that the data obtained from the interviews that have been transcribed are based on the participants' statements. The researchers returned the result of the transcription to the participants to be reviewed. As mentioned by Creswell and Creswell (2018), to examine the credibility of qualitative findings, the researcher is taking back the final report or specific description or themes to the interviewee to check whether the findings are valid or not.

The researchers also conducted member checking. The purpose of the member checking was to make sure that there were no apparent mistakes when doing transcription (Gibbs, 2007, as cited in Creswell and Creswell, 2018). Second, the researchers compared the data and code and wrote memos about the codes and their definitions. Afterward, the researchers did an intercoder agreement. In this intercoder agreement, the researchers found other researchers to ensure this research has a reliable result (Gibbs, 2007, as cited in Creswell \& Creswell, 2018).

\section{Findings}

\section{Online Learning Tools}

Regarding online learning tools that the teachers employed in the teaching and learning process during the COVID-19 pandemic, they claimed that they used some online learning tools. Out of eight categories based on Atmojo and Nugroho (2020), the researchers found six online learning tools that the teachers used in this research. These tools are learning management systems, chat and message tools, assessment tools, video conferencing tools, video streaming, sharing tools, and content maker tools. The following categories are explained as follow:

Learning Management Systems. The first finding is learning management systems. There are two different tools used by EFL teachers, namely Google Classroom and Moodle. In this pandemic, the EFL teachers explained that if they need online learning tools which could be used to assist them in teaching the student. Belle and Aurora chose Google Classroom, while Cinderella and Aladdin chose Moodle. Belle said, "During the pandemic, I used Google 
Classroom to support the learning process instead of Zoom.” Aurora thought that the most online learning tool used during a pandemic was Google Classroom. "I used Google Classroom," she stated. However, Aladdin explained, "I used Moodle because the school has provided it." Then, Cinderella also used Moodle because the school has provided it. "At first, I used another tool, but since school has its policy, so I followed the rules," she explained. The participants agreed that LMS during pandemics could ease them to teach during the COVID- 19 pandemic.

Assessment Tools. EFL teachers also used online learning tools like Google Form to help them assess the students. Using assessment tools, they claimed that it helped them distribute the assessment to the students. Belle, Aurora, and Elsa used this tool while the other participants used different assessment tools. Cinderella and Aladdin only used LMS since LMS also could be a platform to provide an assessment. Belle, Aurora, and Elsa had the same thought for the assessment tools. They said, "For the assessment tools, I used Google Form." They further claimed that if the students had no complaints about the tools, Belle, Aurora, and Elsa still used Google Form as an assessment tool from the beginning of the pandemic. Meanwhile, Aladdin and Cinderella agreed if LMS also could facilitate them to provide the assessment. They just put the assignments, assessments, or quizzes in the LMS then the students would do on the LMS. They claimed, "For the activities, we used LMS only. Ms."

Video Conferencing Tools. Another finding of online learning tools is the video conferencing tool. Included in this category are Google Meet, Microsoft Teams, and Zoom. Belle, Aladdin, and Cinderella believed that using video conferencing tools will help the teacher in the teaching and learning process in the pandemic era. However, each participant used different video conferencing tools. This research found that Belle used Google Meet, Cinderella used Microsoft Teams, and Aladdin used Zoom. Even though they used different online learning tools, they all agreed if video conferencing tools were used to facilitate an online, face-to-face meeting. Also, they used video conferencing tools to obey the school policy to have an online meeting. "I rarely have conference meetings with my students, but somehow I used Google Meet," said Belle. While Cinderella said, "My school provides Teams' account to the students. That is why I used Microsoft Teams during a pandemic." Then, Aladdin said, "Since my School has subscribed to Zoom, that is why I used Zoom. 
Chat and Message Tools. The subsequent finding is chat and messages tools. The chat and messages tool used in this research was WhatsApp. All participants used WhatsApp to teach and learn during the COVID-19 pandemic. Belle, Cinderella, Aladdin, Elsa, and Aurora have the same thought in this finding. They used WhatsApp because the students used WhatsApp to communicate. "Because our students commonly use WhatsApp," they said. They further explained that WhatsApp helped them distribute the information, materials, link, and quizzes.

Video Streaming and Sharing Tools. Another finding is video sharing and learning. One of the video streaming and sharing tool is YouTube. YouTube is a widely used tool by the participants. Through this platform, Belle, Aladdin, Cinderella, Elsa, and Aurora could share their video learning from YouTube or upload the video they have made to YouTube and the link shared to their students. They stated, "I chose YouTube because I think YouTube provides many videos learning. Also, I can share my video there."

Content Maker Tools. The last online learning tool is content maker tools. There are PowToon and Screen O Matic. Aladdin and Belle also used content maker tools to support them in making material content. For instance, Aladdin made an English video using Screen O Matic, and Aurora used PowToon to make animation slides so that the students did not feel bored with the visual. Aladdin mentioned, "I used Screen O Matic to make video learning." While Aurora stated, "Sometimes, I used PowToon to make presentation slides. It gave a more visual content."

\section{EFL Teacher's Consideration}

Besides mentioning the online learning tools used by the EFL teachers, the EFL teachers also explained the consideration in choosing the online learning tools. The detail of the considerations are as follows:

Easy-to-use. The first consideration that the teachers used in choosing the online learning tools are that the tools should be easy to use. EFL teachers claimed that the tools could quickly check the students' assignments, develop the assignment, and monitor the students when they are absent and doing their assignments. Moreover, Belle and Aurora said that using online learning tools is easy to manage and user-friendly. They further explained that to join the Google Classroom. The students click the link provided by the EFL teacher and find the materials, 
YouTube's link, and quizzes there. Elsa claimed, "Using online learning tools during pandemic makes it easier for me to teach because it is effortless." Aurora explained by using the LMS. She did not get any confusion. This view is similar to Belle's, who stated, "In choosing online learning tools during a pandemic, the tools should be considered as adaptable. The reason why is because we should provide the students with the tools without burdening them." She also added, "Google Form makes it easy for me to develop the assignment.” Also, Elsa has the same views. She stated, "Google forms make it easier for me to check the answer when I give assignments."

Accessible. The second consideration that teachers use in choosing the tool should be accessible. The consideration is that during COVID-19, not all the students can access the material on time with the schedule. For instance, the signal makes the students have difficulty accessing the material on time. Moreover, Belle, Aladdin, and Aurora claimed the tools also could be used to store all materials, assessments, and assignments centralized. So, this is also a consideration. Students can open it anytime if they cannot access it on schedule. Aladdin said, "The material is already on the E-learning so that the students can access it anytime, like in the morning, afternoon, and evening." While Aurora said, "based on my experience, they do not do it right away. So, if the students miss it, they can still check it on Google Classroom.” Belle also said, "Yes, it is accessible for the students." Therefore, the EFL teachers found that the online learning tools should be flexible for the students to still learn without time limitations.

Also, the tool should be easy to use by the students. They claimed that it would make the students easy to access. The online learning tool used by the EFL teachers was WhatsApp. WhatsApp is well-known among the students compared to other tools such as Telegram and Line. Belle claimed, "Everyone used it. So, it is easy for students to access too." Then Aurora also stated, "The reason why I used WhatsApp is that all students used this tool. So, I am looking for something that can be accessed by students too." Therefore, the EFL teachers found that the online learning tools should be accessible to learn without time limitations.

Cost-effective. Another consideration is that the tools that the teachers use should be cost-effective. EFL teachers mentioned that they should consider internet data since not all students can purchase internet data for an online school. Therefore, in this finding, the EFL teachers used Google Classroom and WhatsApp groups to conduct online learning during the 
COVID-19 pandemic. Aurora stated, "Google Classroom consumes less internet quota than using another tool such as Zoom." Belle also stated, "But compared to Zoom, Google Classroom is cost-effective. Then, while using Zoom, also buffering when you do not have much quota." The views are similar with Elsa, she said,

"Also, it turned out that when I contacted students and asked them to join, it was difficult because from that point of view, the signal was not there, and the quota was also limited. So, it is a problem. Therefore, instead of students not taking classes well, I would rather choose an alternative that is indeed a low budget that did not put pressure on them and can invite them to take part in learning."

She found that using the cost-effective online learning tools could help them conduct online learning more effectively than using online learning tools that consume much quota, but the students rarely join.

Interesting. One of the considerations that the teachers used to choose the tools they will use is interesting. It means that the tool provides more pictures, animation, video, and audio. So that students will be more engaged in learning. This research found that YouTube is one of the online learning tools chosen by EFL teachers to provide visual learning. The consideration is so that the students will not get bored. Elsa said, "Students will be more engaged in learning because the media is interesting." Aladdin and Elsa also mentioned, "Actually, this tool is for variation. Suppose the video involves all aspects, including visual and audio. If it is text only, then it will be boring."

Lightweight. Moreover, the last consideration is that the tool used must be lightweight. It means the media must have a small megabyte size because if the size of the tool used is too large, such as one hundred megabytes, this will hinder the material creation process. It happens because the laptop used by the EFL teacher is not adequate. Elsa mentioned, "To present the material, I used PowToon, Ms. It could also be PowerPoint 2019, but because it is heavy and my device is not too adequate, so, I just used PowToon.” 


\section{Discussions}

The findings implied that EFL teachers are aware of during COVID-19 pandemic need to use online learning tools. These tools can help and support them in conducting online learning. Reimers et al. (2020) stated that tools could help teachers manage their learning. The EFL teachers used some online learning tools for their classes. The online learning tools include learning management systems, chat and messages, assessment tools, video conferencing tools, video streaming and sharing, and content maker. These online learning tools are similar to the study conducted by Atmojo and Nugroho (2020). They found eight categories. Meanwhile, there are only six categories that EFL teachers use in these findings.

The following finding is EFL teachers' consideration. The first reason is that these online learning tools are easy to operate. The tool does not make the EFL teacher feel confused when using it. The online learning tools found Google Classroom, LMS, Screen-O-Matic, and Google Form user-friendly. This was supported by the result from a study by Gunawan et al. (2020) showing that lectures used Google Classroom and LMS because they were easy to manage. The lecturers mentioned that the tools eased them to manage their classroom. This is also in line with the study from Ventayen et al. (2018), implying that Google Classroom was easy to operate and was recommended for the teachers. Ventayen et al. (2018) further mentioned that this tool provided complex features that supported lecturers' and students' needs.

In conclusion, English teachers chose online learning tools that were easy to use during the pandemic. The second consideration is accessible. The EFL teachers claimed that the tool should be accessible for the students. They mentioned that not all students are in the same situation to check their learning immediately. So, the EFL teachers used the tools that would give them flexibility. Besides, the EFL teachers chose the tool used by the students not to burden them and give them flexibility. Gunawan et al. (2020) stated that lecturers' most widely used online platform is WhatsApp because lecturers and students have this application installed on their smartphones. Besides that, many students claimed that they like using WhatsApp because WhatsApp can be used everywhere and anytime. In this study, the teachers or lecturers choose 
specific online learning tools because of their accessibility. It helps them conduct the class because it can be conducted anywhere and anytime.

The third consideration is cost-effective. The EFL teachers claimed that many students told them they could not purchase much internet quota. Therefore, the EFL teachers chose Google Classroom because it was cost-effective. Atmojo and Nugroho (2020) stated that EFL teachers chose Google Classroom because it consumes less internet data. The fourth finding is intriguing. The EFL teachers claimed they needed to provide learning media during the pandemic that encouraged them to teach and learn. Therefore, one of the online learning tools that EFL teachers chose is YouTube and PowToon. Almurashi (2016) mentioned that students are interested in watching YouTube because it provides video and audio aspects. The last consideration is lightweight. Since the teaching and learning process is conducted online, the online learning tools should be lightweight.

\section{Conclusion and Implication}

Online learning tools can be defined as media that help teachers in the teaching and learning process by utilizing devices with internet access. The purposes of this research were to explore the online learning tools used by EFL teachers along with their consideration. The design of this research was descriptive qualitative. The instrument of this research was an interview to gather the data. The research was conducted in five different state senior high schools in Yogyakarta with five EFL teachers; four females and one male. The participants' names were changed into pseudonyms to keep their confidence and privacy.

This research is to investigate online learning tools and their consideration. Regarding findings, online learning tools used by each EFL teacher can be different. This research uses learning management systems, chat and messages, assessment tools, video streaming and sharing, video conferencing tools, and content maker tools. The EFL teachers explained that using online learning tools during the COVID-19 pandemic helped them maximize online learning during the COVID-19 pandemic. The EFL teachers' consideration in choosing the online learning tool is easy-to-use, accessible, cost-effective, attractive, and lightweight. 


\section{References}

Almurashi, W. A. (2016). The effective use of Youtube videos for teaching English language in classroom as supplementary material at taibah in university in Alula. International Journal of English Language and Linguistic Research, 4(3), 32-47.

Atmojo, A. E. P., \& Nugroho, A. (2020). EFL classes must go online! teaching activities and challenges during the COVID-19 pandemic in Indonesia. Register Journal, 3(1), 49-76. https://doi.org/10.18326/rgt.v13i1.49-76

Creswell, J.W., \& Creswell, J.D. (2018). Research design: Qualitative, quantitative, and mixed methods approach. Fifth Edition. Los Angles: SAGE. Ch.9, Qualitative Method, 179. 211.

Dhawan, S. (2020). Online learning: A panacea in the Time of COVID-19 Crisis. Journal of Educational Technology System, 49(1), 5-22. https://doi.org/10.1177/0047239520934018.

Donche, V., \& Petegem, P. V. (2010). The relationship between entry characteristics, learning style and academic achievement of college freshmen. In M. E. Poulsen (Eds.), Higher Education: Teaching, Internationalizations and Students issues (pp. 2-12). Nova Science Publisher, Inc.

Eady, M. J., \& Lockyer, L. (2013). Tools for learning: Technology and teaching strategies. The Queensland University of Australia.

Gunawan., Suranti, N. M. Y., \& Fathorni. (2020). Variations of Model and Learning Platforms from Prospective Teachers During the COVID-19 Pandemic Period. Indonesian Journal of Teachers Education, 1(2), 61-70. Retrieved from https://journal.publicationcenter.com/index.php/ijte/article/view/95

Hamat, A., \& Embi, M., A. (2010). Constructivism in the design of online learning tools. European Journal of Educational Students, 2(3), 237-246.

Lambert, V.A., \& Lambert, C.E. (2012). Descriptive research: An acceptable design. Pacific Rim International Journal of Nursing Research, 16(4), 255- 256.

Merriam, S.B. (1998). Qualitative research and case study applications in education. San Francisco: BirJossey-Bass Publishers.

Ministry of Education and Culture. (2020, March 24). Mendikbud terbitkan SE tentang pelaksanaan pendidikan dalam masa darurat COVID-19 [Minister of Education and Culture issued a circular letter on the implementation of education during the emergency period of COVID-19]. Ministry of Education and Culture. https://www.kemdikbud.go.id/main/blog/2020/03/mendikbud-terbitkan-se-tentang pelaksanaan-pendidikan- dalam-masa-darurat-covid19 
Reimers, F., Schleicher, A., Saavedra, J., \& Tuominen, S. (2020). Supporting the continuation of teaching and learning during the COVID-19 pandemic. OECD.

https://www.oecd.org/education/Supporting-the- continuation-of-teaching-and-learningduring-the- COVID-19-pandemic.pdf.

Ryan, F., Coughlan, M., \& Cronin. P. (2009). Interviewing and qualitative research: The oneto-one interview. International Journal of Therapy and Rehabilitation, 16(6), 309-314. https://doi.org/10.12968/ijtr.2009.16.6.42433

UNESCO. (2020, May 25). Education: From disruption to recovery. https://en.unesco.org/covid19/educationresponse.

Ventayen, R. J. M., Estira, K. L. A., De Guzman, M. J., Cabaluna, C. M., \& Espinosa, N. N. (2018). Usability evaluation of Google Classroom: Basis for the adaptation of gsuite elearning platform. Asia Pacific Journal of Education, Arts, and Sciences, 5(1), 47-51. 